\title{
BLOOD PROFILE OF WEST AFRICAN DWARF (WAD) BUCKS FED RAW AND PROCESSED COCOA POD HUSK MEAL BASED - DIETS IN THE HUMID HIGH RAINFOREST ZONE OF NIGERIA
}

\author{
ANYA. M. I., OZUNG P.O. AND IGWE P.A.
}

(Received 5 June 2018; Revision Accepted 3 July 2018)

\begin{abstract}
A 12-week feeding trial was carried out using 30 West African Dwarf (WAD) bucks of age between six and eight months with mean initial body weight of $9.36 \pm 1.31 \mathrm{~kg}$, to determine the effect of sun-dried, urea-treated and fermented dietary cocoa pod husk meal (CPHM) as well as dietary CPHM with protein supplementation (African yam bean meal) on blood characteristics. Five experimental diets: $\mathrm{T}_{1}$ ( $0 \%$ CPHM-control), $\mathrm{T}_{2}$ (40\% sundried $\left.\mathrm{CPHM}\right), \mathrm{T}_{3}(40 \%$ ureatreated $\mathrm{CPHM}), \mathrm{T}_{4}$ (40\% fermented $\left.\mathrm{CPHM}\right)$ and $\mathrm{T}_{5}(40 \% \mathrm{CPHM}$ and $10 \%$ African yambean) were formulated. Six animals per treatment were randomly assigned to the experimental diets using a CRD. Blood parameters (haematological and serum biochemical indices) were evaluated at the end of the feeding trial. Results of the study showed that the White blood cell counts, packed cell volume and red blood cell counts were significantly $(P<0.05)$ influenced by dietary treatments. In terms of serum chemistry, higher values of urea were recorded in sundried (6.57 $\mathrm{mmol} / \mathrm{l})$ and protein supplemented $(6.57 \mathrm{mmol} / \mathrm{l})$ groups, followed by the fermented group $(6.17 \mathrm{mmol} / \mathrm{l})$. Calcium $(2.24$ $\mathrm{mmol} / \mathrm{l})$ and total protein $(7.44 \mathrm{~g} / \mathrm{dl})$ were highest in urea-treated CPHM group followed by the protein supplemented group $(1.84 \mathrm{mmol} / \mathrm{l}$ and $7.37 \mathrm{~g} / \mathrm{dl})$ and lowest in the sundried CPHM group $(1.14 \mathrm{mmol} / \mathrm{l}$ and $6.21 \mathrm{~g} / \mathrm{dl})$ respectively. The study concludes that blood composition of WAD bucks was best in the urea-treated and protein supplemented groups respectively, and $40 \%$ cocoa pod husk meal supplemented with $10 \%$ protein (African yambean) can be incorporated in the diets of WAD bucks without fear of compromising haematological and serum biochemical indices.
\end{abstract}

\section{KEYWORDS: Cocoa pod husk, Urea, Fermented, Protein supplemented, WAD bucks}

\section{INTRODUCTION}

Goats play a significant role in supplying protein to humans and paying close attention to their feed supply will to a great extent increase their productivity. They are highly productive and are reared not just as a source of income to the farmers but also provide milk and meat (Jansen and Van Den Burg, 2004). Their feeding behaviour, fast maturity, reproductive efficiency, small body size (Adugna et al., 2000) and ability to thrive well in harsh weather conditions (Jansen and Van Den Burg, 2004) are important attributes that make goat keeping a choice venture. Fluctuations in weather, limited grazing lands, soil infertility, competition between human and animals for food and high cost of feed are some of the factors that hinder the productivity of goats.

To reduce feed cost and solve the problem of feed availability, farmers have resorted to the use of nonconventional feed ingredients to maintain their animals and in some cases to totally replace maize as an energy source in animal feeds (Esong et al., 2015). This may be attributed to the nutrient qualities hidden in them. Supplementations with legume plants as well as the use of agro-industrial by-products have in recent times proven to be successful.

Legumes are usually planted for use as supplements to improve animal productivity in periods of limited forage availability. Leucaena leucocephala and Gliricidia sepium have been reported to be widely used in supplementing animals on crop residue as well as byproducts of agricultural processing (Norton, 1998). If the supplementation is done adequately there will be an efficient utilization of crop residues. The animals can either be allowed to browse these plants for a limited time (to avoid tree damage) or preferably fed with the already cut forages. The limitation in the use of most crop residues is that majority of them have a characteristically high crude fibre and low protein contents. However, their nutritional quality can be improved when subjected to various treatments (physical, biological and chemical treatments). The structural carbohydrates of the cell wall become more

\footnotetext{
Anya. M. I., Department of Animal Science, University of Calabar, Calabar, Nigeria

Ozung, P.O., Department of Animal Science, University of Calabar, Calabar, Nigeria

Igwe, P.A., Department of Animal Science, University of Calabar, Calabar, Nigeria
} 
easily digestible by the action of rumen microbes and/or digestive enzymes when these crop residues are treated with urea (Khajarern and Khajarern, 1985).

Fermentation as a process is used to break down larger molecules into simpler forms with alcohol as its end product and it has been an age long practice in the food and wine industry (Alber-Lois and Segal-Kischinevzky, 2010). In the cocoa industry, fermentation which usually lasts 5 days is employed on the beans for the production of chocolate and cocoa related products (ICCO, 1998). Cocoa (Theobroma cacao) is a tree crop of about 20 to $40 \mathrm{ft}$. in height. It originated in Mexico but has spread throughout Africa and found majorly in the tropical rainforest zone of Nigeria (Joachim and Felicitas, 2000). Cocoa pod husk is a by-product of cocoa processing and about 1.8 million tons are generated yearly in cocoa producing areas of Nigeria (Opeke, 2005). However, this crop residue constitutes nuisance to the environment because of poor waste management procedures. However, over the years, the development of new technologies, ideas and techniques have led to the use of this by-product as an alternative to conventional feeds for animals (Nwanze, 2014).

Cocoa pod husks contain energy, fibre and minerals (Agunbiade et al., 2002) which are the choice nutrients in ruminant nutrition. The crude protein content is about $7.5 \%$, crude fibre, $23.4 \%$; ash, $7.4 \%$; ether extract $2.5 \%$ (Fagbenro, 1995) and gross energy content of $3.990 \mathrm{Mcal} / \mathrm{kg}$ (Wong and Wan Zahari, 1997). Dried cocoa pod husk (pelleted) can be used as a substitute for maize and wheat bran in formulating rations for chickens, pigs and sheep and at optimal inclusion levels will not pose any risk to the animal (ICCO, 2000). Cocoa contains flavonoids, an antioxidant necessary for the proper functioning of the heart and brain (Coe and Coe, 1996). The nitrogen content of cocoa is made up of two water-soluble alkaloids; theobromine and caffeine which can be tolerated to an extent by humans but not so by animals (Oyadeyi et al., 2011). Because of the theobromine in the husk though in small amounts (Abiola and Tewe, 1991), as well as the high crude fibre and low protein contents (Sutikno, 1997), there is the need to subject the husk to different treatments, such as physical (sun-drying), chemical (urea treatment) and biological (fermentation) to improve not only the nutritional qualities but also the digestibility of this feed resource.

Blood contain a myriad of metabolites and other constituents which will provide a valuable medium for clinical investigation (disease prognosis) and nutritional status of animals. Dietary components have been reported to have measurable effects on blood profile; hence blood constituents are widely used in nutritional evaluation and survey of animals (Ewuola and Egbunike, 2008). Blood is a very important tissue of an animal's body (Turner et al., 2008). It is a fluid that functions in oxygen, nutrients and waste transport and also involved in the mechanism of heat exchange. Merck manual (2012) defined haematology as the study of the number and morphology of the cellular elements of the blood - the RBCs (erythrocytes), WBCs (leukocytes) and platelets (thrombocytes) and the use of these results in the diagnosis and monitoring of diseases. Serum on the other hand is a fluid that is similar to plasma except for the absence of coagulation protein (Turner et al., 2008). It is seen only when there is a blood clot. It is an indication of the wellness or abnormality of organs and tissues as well as general metabolism of the body (Vetstreet, 2011).

The healthiness of haematological parameters to a large extent depends on the quality of feed ingested and the anti-nutrients present in the feed while serum chemistry is influenced by the toxic elements in the feed (Akinmutimi, 2004). This study was therefore designed to determine the effect of raw and processed cocoa pod husk meal on the blood profile (haematology and serum chemistry) of WAD goats (bucks) in a humid zone of Nigeria.

\section{Material and Methods}

\section{Location of the study}

The study was carried out at the Sheep and Goat Unit of the Teaching and Research Farm, Department of Animal Science, University of Calabar, Calabar, Cross River State. According to GeoNames geographical database (Goggle Earth, 2016), Calabar, a humid tropical region of Nigeria is located at $4.958^{\circ}$ latitude and $8.326^{\circ}$ longitude (decimal degrees) with an average of 37 metres above sea level. The mean rainfall is about $1830 \mathrm{~mm} / a n n u m$ while average temperature is between 25 and $30^{\circ} \mathrm{C}$ (NMA, 2018). The vegetation is majorly mangrove which consists of shrubs and trees (Okpiliya et al., 2013).

\section{Processing of cocoa pod husk meal (CPHM)}

\section{Sources of cocoa-pod husk}

Composite fresh husks of cocoa pod of forastero variety were collected from Ndibiji village as well as Ojor and Owai communities of Uyangha, Akamkpa Local Government Area of Cross River State. The husks were washed, broken and subjected to different treatment procedures as follows:

\section{Sun-dried cocoa pod husk meal (SCPHM)}

A total of $200 \mathrm{~kg}$ of the already washed cocoa pod husks was measured using a $20 \mathrm{~kg}$ top loader weighing scale and were cut into pieces and sundried on a clean concrete slab to constant weight and afterwards milled with a hammer mill of $5 \mathrm{~mm}$ sieve size. The sun-dried cocoa pod husk meal was then stored in polythene bags for use in compounding the experimental diet as SCPHM.

\section{Urea - treated cocoa pod husk meal (UCPHM)}

A total of $200 \mathrm{~kg}$ of the already washed cocoa pod husks were cut into pieces, placed on a clean cemented floor and allowed to dry for 6 days. They were then milled with a hammer mill of $5 \mathrm{~mm}$ sieve size to obtain cocoa pod husk meal. The meal was then treated with urea on a volume/weight basis as stated by lyayi et al. (2001). Exactly $1 \mathrm{~kg}$ of urea was dissolved in 25 litres of water. The solution obtained was thoroughly mixed with $25 \mathrm{~kg}$ of the cocoa pod husk meal after which the meal was put in a thick polyethene bag and tied firmly so as to exclude air. The treated CPHM was kept under shade for 2 weeks after which the meal was then air- dried for 
4 days and ready for use in compounding experimental diet.

\section{Fermented cocoa pod husk meal (FCPHM)}

A total of $200 \mathrm{~kg}$ of freshly broken and washed cocoa pod husks were dried for 6 days, milled $(5 \mathrm{~mm}$ sieve size) and mixed with 60 percent of water as described by Bello et al. (2012). Thereafter the meal was put in polyethene bags to ferment (anaerobically), labelled and kept in a room for 3 days after which the meal was dried under shade for 5 days, then bagged and stored for compounding of experimental diets.

\section{Processing of the protein feedstuff (African yam bean)}

African yam bean (Sphenostylis sternocarpa) seeds used in this study were boiled for 60 minutes as outlined by Ukachukwu and Obioha (2000) for mucuna seeds. Borehole water was made to boil at $100{ }^{\circ} \mathrm{C}$ before the seeds were poured in. Boiling continued for 60 minutes.
At the end of the boiling, water was drained off using a local basket and sundried on a clean concrete slab for 6 days. The seeds were then milled, stored in a bag and ready for compounding the experimental diets.

\section{Experimental diets}

Five (5) experimental diets were compounded to meet the goats' nutrient requirements. The diets were designated as $\mathrm{T}_{1}$ (control), $\mathrm{T}_{2}$ (sun-dried), $\mathrm{T}_{3}$ (ureatreated), $T_{4}$ (fermented) and $T_{5}$ (protein supplemented African yam bean meal). Diet $T_{1}$ contained neither cocoa pod husk meal nor protein feedstuff, but rather contained conventional feedstuff like maize and soybean. Diets $T_{2}, T_{3}, T_{4}$ and $T_{5}$ contained differently treated cocoa pod husk meal at fixed rate (40 percent) with $T_{5}$ containing protein feedstuff (10 percent African yam bean meal). All other basic ingredients were used to formulate the diets as shown in Table 1. Proximate compositions were determined based on AOAC (1990) methods. Each sample was analysed three times (triplicate determinations) per proximate parameter.

Table 1: Gross composition of experimental diets

\begin{tabular}{llllll}
\hline Ingredient (\%) & $\begin{array}{l}\mathrm{T}_{1} \\
\text { (Control) }\end{array}$ & $\begin{array}{l}\mathrm{T}_{2} \\
(\mathrm{SCPHM})\end{array}$ & $\begin{array}{l}\mathrm{T}_{3} \\
(\mathrm{UCPHM})\end{array}$ & $\begin{array}{l}\mathrm{T}_{4} \\
(\mathrm{FCPHM})\end{array}$ & $\begin{array}{l}\mathrm{T}_{5} \\
\text { (Protein Supp.) }\end{array}$ \\
\hline SCPHM & - & 40 & - & - & 40 \\
UCPHM & - & - & 40 & - & - \\
FCPHM & - & - & - & 40 & - \\
AYB & - & - & - & - & 10 \\
Maize & 40 & - & - & - & - \\
SBM & 10 & - & - & - & 24 \\
Wheat offal & 24 & 24 & 24 & 24 & 25 \\
PKC & 25 & 35 & 35 & 35 & 0.5 \\
Vit. Min. Premix & 0.5 & 0.5 & 0.5 & 0.5 & 100 \\
Salt & 0.5 & 0.5 & 0.5 & 0.5 & \\
Total & 100 & 100 & 100 & 100 & 13.68 \\
Calculated & & & & & 15.85 \\
analysis: & 17.86 & 13.31 & 13.69 & 13.06 & 2534.60 \\
\% CP & 10.81 & 16.96 & 15.96 & 15.66 & \\
\%CF & 2900.05 & 2424.13 & 2463.43 & 2476.12 & \\
ME(Kcal/kg) & & & & &
\end{tabular}

SCPHM- Sun-dried cocoa pod husk meal

UCPHM - Urea-treated cocoa pod husk meal

FCPHM - Fermented cocoa pod husk meal

AYB- African yam bean

SBM-Soybean meal

PKC- Palm kernel cake

\section{Experimental animals and management}

Thirty (30) WAD bucks of age between 6 and 8 months with mean initial weight of $9.36 \pm 1.54 \mathrm{~kg}$ were used in this study. The animals were bought from local farmers at Akpabuyo, Cross River State, Nigeria. They were given anti-stress (lytavite) on arrival and were housed in concrete floored pens with two open sides provided with thick wire mesh for ventilation. The bucks were quarantined for 14 days and were fed sun-dried yam peels and forage materials (Penisetum purpureum and Pueraria phaseloides). At the beginning of the study, the animals were randomly allocated to different treatments after balancing for body weight with six animals per treatment and each serving as a replicate in a Completely Randomized Design (CRD) experiment. During the quarantine period, long-acting antibiotic (oxytetracyline) was administered intravenously and repeated after 4 days to take care of any infection. One bolus of albendazole was administered orally to each of the goats for the control of endo-parasites and Ivermectin injection at $2 \mathrm{ml} / \mathrm{goat}$ was administered for the treatment and prevention of ecto parasites (mange). Also vaccination was done against Kata or PPR (Pestes des petites ruminants). The animals were given clean water ad-libitum and pens were cleaned on a daily basis 
throughout the duration of the study which lasted for 12 weeks.

\section{Housing and equipment}

The goat unit was partitioned into 30 pens of $1.8 \times 1.75$ $\mathrm{m}$ each using planks of $12 \times 1 \mathrm{ft}, 2 \times 2$ inches wood and ply wood of $1.2 \times 2.4 \mathrm{~m}$, grouped according to the different treatments thereby providing an area of $3.15 \mathrm{~m}^{2}$ for each of the goats. The floor was cemented but wooden elevation was provided to guard against cold. Air circulation was not a problem as the two sides of the unit were open but secured with a strong wire mesh to prevent thieves and predators from gaining access. Durable plastic watering and feeding troughs were made available for each goat.

\section{Blood collection and determination of haematological and serum biochemical indices}

At the end of the feeding trial $\left(12^{\text {th }}\right.$ week), two sets of blood samples $(10 \mathrm{ml})$ from each animal per treatment were taken from the jugular vein using a syringe and needle into clean bottles. One set was introduced in bottles containing anticoagulant, ethylene diamine tetraacetate (EDTA) for the determination of haematological parameters, while the second set of blood samples were in clean bottles devoid of the anticoagulant for the determination of serum biochemical parameters. Each haematological parameter was determined in triplicates using the methods of Baker and Silverton (1978). Serum biochemical indices were also determined in triplicates by methods described by Peter et al. (1982); Kohn and Allen (1995); Ochei and Kolhather (2007).

\section{Statistical analysis}

All data obtained in this study were subjected to one way analysis of variance for CRD. Significant means were separated using Duncan Multiple Range Test (Duncan, 1955).

\section{Results}

The result of the proximate composition of processed cocoa pod husk meal (CPHM) is shown in Table 2. The result revealed that the crude protein content of the sundried CPHM (8.53 percent) is not statistically different from that of the urea treated CPHM $(9.47$ percent). The lowest value was recorded in the fermented cocoa-pod husk meal (7.98 percent). Ether extracts had higher values in fermented cocoa-pod husk meal (3.59 percent), with a lower value in urea-treated cocoa pod husk meal (3.26 percent). Sundried cocoapod husk meal recorded higher value of 25.89 percent in crude fibre content with lower values recorded in fermented cocoa-pod husk meal (22.65 percent). The composition of ash in the sun-dried fermented and ureatreated CPHM were $4.95,5.16$ and 4.38 percent respectively and NFE values of $46.09,50.05$ and 51.76 percent, respectively.

The proximate composition of the diets containing $\mathrm{CPHM}$ is presented in Table 3 . The crude protein, ether extract and NFE recorded significant differences $(\mathrm{P}<$ $0.05)$ across dietary treatments.

Table 2: Proximate composition of the processed cocoa pod husk meal (CPHM)

\begin{tabular}{lclll}
\hline Parameters (\%) & SCPHM & FCPHM & UCPHM & SEM \\
\hline Dry matter & 88.87 & 89.33 & 88.76 & 0.14 \\
Crude protein & 8.53 & 7.98 & 9.47 & 0.36 \\
Ether extract & 3.41 & 3.59 & 3.26 & 0.08 \\
Crude fibre & 25.89 & 22.65 & 23.41 & 0.80 \\
Ash & 4.95 & 5.16 & 4.38 & 0.19 \\
NFE & 46.09 & 50.05 & 51.76 & 2.37 \\
\hline
\end{tabular}

All mean values were obtained from triplicate determinations

SCPHM- Sun-dried cocoa pod husk meal

UCPHM - Urea-treated cocoa pod husk meal

FCPHM - Fermented cocoa pod husk meal

Table 3: Proximate composition of diets containing CPHM

\begin{tabular}{lllllll}
\hline $\begin{array}{l}\text { Parameters } \\
(\%)\end{array}$ & $\mathrm{T}_{1}$ & $\mathrm{~T}_{2}$ & $\mathrm{~T}_{3}$ & $\mathrm{~T}_{4}$ & $\mathrm{~T}_{5}$ & SEM \\
(Control) & $(\mathrm{SCPHM})$ & $(\mathrm{UCPHM})$ & (FCPHM) & (Protein supp.) & \\
\hline Dry matter & 90.35 & 89.27 & 89.21 & 89.17 & 89.37 & 0.27 \\
Crude protein & 18.42 & 12.75 & 13.21 & 12.83 & 13.84 & 0.96 \\
Crude fibre & 10.85 & 26.80 & 25.89 & 21.84 & 23.78 & 3.08 \\
Ether extract & 4.75 & 2.67 & 2.74 & 3.13 & 3.26 & 0.33 \\
Ash & 7.02 & 6.43 & 6.40 & 6.36 & 6.51 & 0.11
\end{tabular}




\begin{tabular}{lllllll} 
NFE & 49.31 & 40.62 & 40.97 & 45.01 & 41.98 & 3.26 \\
\hline
\end{tabular}

All mean values were obtained from triplicate determinations

\section{Haematological characteristics of WAD bucks fed diets containing CPHM}

The result of the haematological parameters is shown in Table 4. All the parameters measured were significantly $(P<0.05)$ different between dietary treatments except neutrophils, eosinophils, basophils and mean corpuscular volume.

Table 4: Haematological characteristics of WAD bucks fed diets containing CPHM

\begin{tabular}{|c|c|c|c|c|c|c|c|}
\hline Parameter & $\begin{array}{l}\mathrm{T}_{1} \\
\text { (Control) }\end{array}$ & $\begin{array}{l}\mathrm{T}_{2} \\
(\mathrm{SCPHM})\end{array}$ & $\begin{array}{l}\mathrm{T}_{3} \\
\text { (ÜCPHM) }\end{array}$ & $\begin{array}{l}\mathrm{T}_{4} \\
(\mathrm{FCPHM})\end{array}$ & $\begin{array}{l}\mathrm{T}_{5} \\
\text { (Protein } \\
\text { supp) }\end{array}$ & SEM & $\begin{array}{l}\text { Ref. } \\
\text { ranges }\end{array}$ \\
\hline WBC $\left(\times 10^{9} / L\right)$ & $20.51^{b}$ & $12.14^{\mathrm{C}}$ & $36.34^{a}$ & $23.40^{b}$ & $31.18^{a}$ & 2.39 & $17.5-19.9^{* * *}$ \\
\hline PCV (\%) & $10.87^{b}$ & $8.07^{b}$ & $15.87^{\mathrm{a}}$ & $9.17^{\mathrm{b}}$ & $19.51^{a}$ & 1.28 & $21-35^{* *}$ \\
\hline $\begin{array}{l}\text { Haemoglobin } \\
\text { (g/dl) }\end{array}$ & $11.50^{\mathrm{b}}$ & $9.97^{\mathrm{C}}$ & $13.27^{\mathrm{a}}$ & $10.07^{c}$ & $12.20^{\mathrm{ab}}$ & 0.37 & $7-15^{* *}$ \\
\hline $\operatorname{RBC}\left(\times 10^{12} / L\right)$ & $3.41^{\mathrm{b}}$ & $2.51^{\mathrm{b}}$ & $4.85^{\mathrm{a}}$ & $2.89^{b}$ & $5.52^{a}$ & 0.34 & $8-18^{*}$ \\
\hline Platelets $\left(\times 10^{11} / \mathrm{L}\right)$ & $3.10^{a}$ & $2.87^{\mathrm{ab}}$ & $2.27^{\mathrm{b}}$ & $2.19^{b}$ & $3.61^{a}$ & 0.24 & $3.0-6.0^{*}$ \\
\hline Lymphocytes (\%) & $16.83^{b}$ & $19.64^{\mathrm{b}}$ & $30.11^{a}$ & $20.00^{b}$ & $16.40^{\mathrm{b}}$ & 1.51 & $50-70^{*}$ \\
\hline Monocytes (\%) & $9.44^{\mathrm{a}}$ & $7.61^{\mathrm{ab}}$ & $4.71^{\mathrm{c}}$ & $7.14^{\mathrm{ab}}$ & $6.27^{\mathrm{bc}}$ & 0.49 & $0-4^{*}$ \\
\hline Neutrophils (\%) & 65.33 & 66.07 & 66.71 & 66.81 & 67.97 & 1.05 & $30-48 *$ \\
\hline Eosinophils (\% & 5.30 & 4.80 & 4.77 & 6.11 & 5.44 & 0.25 & $1-7^{* *}$ \\
\hline Basophils (\%) & 0.46 & 0.37 & 0.34 & 0.34 & 0.44 & 0.03 & $0.1-0.3^{* * *}$ \\
\hline $\operatorname{MCV}(\mathrm{fl})$ & 32.04 & 30.90 & 31.67 & 31.67 & 31.44 & 0.23 & $16-25^{*}$ \\
\hline $\mathrm{MCH}$ (pg/cell) & $35.14^{a}$ & $36.97^{a}$ & $26.81^{b}$ & $34.84^{a}$ & $23.04^{b}$ & 1.57 & $36-43.2^{* * *}$ \\
\hline $\mathrm{MCHC}(\mathrm{g} / \mathrm{dl})$ & $113.40^{a}$ & $119.17^{a}$ & $83.34^{b}$ & $110.40^{a}$ & $71.34^{b}$ & 5.42 & $30-36^{*}$ \\
\hline
\end{tabular}

All mean values were obtained from triplicate determinations

$a, b, c$ Means along the same row with different superscripts are significantly different $(P<0.05)$

${ }^{*}$ Reference ranges by Fielder (2016)

${ }^{* *}$ Reference ranges by Daramola et al. 2005

${ }^{* * \star}$ Reference ranges by Opara et al. (2010)

\section{Serum biochemical indices of WAD buck fed diets containing CPHM}

The result of the serum biochemical indices is summarised in Table 5. Most of the parameters measured were significantly $(P<0.05)$ different except albumin, triglycerides and glucose. The calcium content
$(2.24 \mathrm{mmol} / \mathrm{l})$ was significantly $(P<0.05)$ higher in ureatreated group with the lowest value in the sundried $(1.14 \mathrm{mmol} / \mathrm{l})$ group. Creatinine recorded higher values in all the groups when compared with the control $(58.67 \mu \mathrm{mol} / \mathrm{l})$ with highest value recorded in the ureatreated group $(91.67 \mu \mathrm{mol} / \mathrm{l})$ and lowest in the sundried group $(74.67 \mu \mathrm{mol} / \mathrm{l})$. 
Table 5: Serum biochemical indices of WAD bucks fed CPHM diets

\begin{tabular}{|c|c|c|c|c|c|c|c|}
\hline Parameters & $\begin{array}{l}\mathrm{T}_{1} \\
\text { (Control) }\end{array}$ & $\begin{array}{l}\mathrm{T}_{2} \\
\text { (SCPHM) }\end{array}$ & $\begin{array}{l}\mathrm{T}_{3} \\
\text { (UCPHM) }\end{array}$ & $\begin{array}{l}\mathrm{T}_{4} \\
\text { (FCPHM) }\end{array}$ & $\begin{array}{l}T_{5} \\
\text { (Protein } \\
\text { supp.) }\end{array}$ & SEM & Ref. ranges \\
\hline Calcium (mmol/l) & $1.17^{\mathrm{C}}$ & $1.14^{\mathrm{C}}$ & $2.24^{\mathrm{a}}$ & $1.63^{b}$ & $1.84^{\mathrm{b}}$ & 0.12 & $1.15-2.4^{*}$ \\
\hline Creatinine $(\mu \mathrm{mol} / \mathrm{l})$ & $58.67^{\mathrm{b}}$ & $74.67^{\mathrm{ab}}$ & $91.67^{a}$ & $88.00^{\mathrm{a}}$ & $80.00^{\mathrm{ab}}$ & 4.07 & $88.4-159^{* *}$ \\
\hline Urea (mmol/l) & $4.57^{\mathrm{b}}$ & $6.57^{\mathrm{a}}$ & $5.57^{\mathrm{ab}}$ & $6.17^{\mathrm{a}}$ & $6.57^{\mathrm{a}}$ & 0.26 & $0.8-9.7^{*}$ \\
\hline Sodium (mmol/l) & $134.00^{\mathrm{a}}$ & $134.33^{\mathrm{a}}$ & $133.33^{a}$ & $128.00^{\mathrm{b}}$ & $134.00^{\mathrm{a}}$ & 0.83 & $124-146^{*}$ \\
\hline Total protein $(\mathrm{g} / \mathrm{dl})$ & $6.34^{\mathrm{bc}}$ & $6.20^{\mathrm{c}}$ & $7.40^{\mathrm{a}}$ & $6.60^{\mathrm{b}}$ & $7.40^{\mathrm{a}}$ & 0.52 & $6.3-8.5^{*}$ \\
\hline Albumin (g/dl) & 2.75 & 2.75 & 2.60 & 2.60 & 2.60 & 0.07 & $2.8-4.3^{*}$ \\
\hline Globulin (g/dl) & $3.65^{b}$ & $3.45^{\mathrm{b}}$ & $4.80^{\mathrm{a}}$ & $4.00^{\mathrm{ab}}$ & $4.80^{\mathrm{a}}$ & 1.13 & $2.7-4.1^{* *}$ \\
\hline A/G Ratio & $0.75^{\mathrm{ab}}$ & $0.80^{\mathrm{a}}$ & $0.54^{\mathrm{c}}$ & $0.65^{\mathrm{b}}$ & $0.54^{\mathrm{c}}$ & 0.09 & $1.03-1.05^{\star \star}$ \\
\hline Cholesterol $(\mathrm{mmol} / \mathrm{l})$ & $2.70^{\mathrm{b}}$ & $3.27^{\mathrm{a}}$ & $3.01^{\mathrm{ab}}$ & $3.08^{\mathrm{ab}}$ & $2.67^{\mathrm{b}}$ & 0.09 & $2.07-3.37^{* *}$ \\
\hline $\mathrm{HDL}(\mathrm{mmol} / \mathrm{l})$ & $1.34^{\mathrm{C}}$ & $1.77^{\mathrm{ab}}$ & $1.91^{\mathrm{a}}$ & $1.61^{\mathrm{b}}$ & $1.70^{\mathrm{ab}}$ & 0.06 & $0.48-0.53^{* * *}$ \\
\hline Triglycerides $(\mathrm{mmol} / \mathrm{l})$ & 0.87 & 1.07 & 0.94 & 0.91 & 1.04 & 0.03 & $0.16-1.6^{*}$ \\
\hline Glucose $(\mathrm{mmol} / \mathrm{l})$ & 4.67 & 3.30 & 3.90 & 3.37 & 3.47 & 0.21 & $2.78-4.16^{\star *}$ \\
\hline
\end{tabular}

\footnotetext{
a, b, c Means along the same row with different superscripts are significantly different $(P<0.05)$. All mean values were obtained from triplicate determinations Ref. ranges - Reference ranges

*Reference ranges by Daramola et al. (2005)

${ }^{* *}$ Reference ranges by Fielder (2016)

Reference ranges by Kasumu (2011)
}

\section{DISCUSSION}

\section{Proximate composition of processed cocoa pod husk meal (CPHM)}

The proximate composition of sundried, fermented and urea-treated CPHM (Table 2) shows that these processing methods contributed to the slight differences in their nutrient contents, even though there were no significant $(\mathrm{P}>0.05)$ differences. The crude protein values for the sundried $(8.53 \%)$ and fermented $(7.98 \%)$ CPHM were lower and higher respectively from the results (9.37 and $7.70 \%$ ) reported by Ozung, et al. (2016). Esong et al. (2015) recorded a crude protein content of $8.00 \%$ for sundried CPHM which is slightly lower than the value obtained in this study and higher than the values reported by Aregheore (2002) (6.20\%) and Adegunloye and Famolu (2016) (6.11\%). The crude protein content for the urea-treated CPHM $(9.47 \%)$ is a little higher than the value $(9.08 \%)$ reported by lyayi et al. (2001). Processing methods may be responsible for the differences in crude protein of the processed CPHM. The higher crude protein value in urea treated CPHM could be as a result of the nitrogen content of urea (Erika and Anuraga, 2015). Cocoa pod husk has been known to contain high fibre (Alexander et al., 2008; Adegunloye and Famolu, 2016; Ozung et al., 2016) and so the higher values in the crude fibre content of the sundried group $(25.89 \%)$ further confirms the earlier findings by other workers. The crude fibre content of fermented CPHM (22.65 \%) was lower than the sundried $(25.89 \%)$ and urea-treated group $(23.41 \%)$. These values are higher than the findings recorded by Adegunloye and Famolu (2016) for unfermented (15.55 $\%)$ and fermented $(7.50 \%)$ and lower than the result obtained by Erika and Anuraga (2015) who recorded 55.7 and $49.10 \%$ for raw and fermented CPHM respectively. Crude fibre in this study for urea-treated CPHM (23.41\%) was higher than the value $(21.0 \%)$ recorded by lyayi et al. (2001) and lower than that (50.9 $\% \mathrm{t}$ ) of Erika and Anuraga (2015). The reduction in the crude fibre content of both fermented CPHM and ureatreated CPHM has been reported to be as a result of the processing methods employed (Erika and Anuraga 2015). This reduction in fibre content is an advantage when CPHM is being considered as feed for animals as the high fibre content serves as a hindrance to its utilization (Sutikno, 1997). The ash content of ureatreated CPHM (4.38 \%) was lower than the value (8.75 $\%)$ recorded by lyayi et al. (2001). The values obtained for the fermented CPHM (5.16\%) and sundried CPHM $(4.95 \%)$ are higher than the results (4.02 and 3.74 percent) recorded by Adegunloye and Famolu, (2016) and lower than the values reported by Ozung et al. (2016) who recorded 10.80 and $9.30 \%$, respectively. These results show that fermentation increases the ash content of CPHM. The higher ash content of fermented CPHM could be as a result of the increased action of microorganisms on the heavier minerals, thereby, breaking them down into lighter ones (Adamafio et al., 2011). The ether extract and nitrogen free extracts for the fermented (3.59 and $49.95 \%)$ respectively are higher than $(2.55 \%)$ and lower than $(68.02 \%)$ reported by Adegunloye and Famolu, (2016) while those of the 
urea-treated CPHM (3.26 and $48.24 \%$ respectively) are higher than the result obtained by Erika and Anuraga (2015) who recorded $25.00 \%$ NFE and $2.20 \%$ ether extract. These variations still points out the fact that the different processing methods affected the nutrient contents of CPHM.

\section{Proximate composition of diets containing CPHM}

The proximate composition of diets containing CPHM (Table 3 ) recorded significant differences $(P<0.05)$ in crude fibre, crude protein, ether extract and NFE among the groups. The crude protein across the diets (12.75$13.84 \%)$ was within the recommended range of 9.00 $14.00 \%$ for growing buck kids (Kieser, 2012). The higher protein contents in $T_{3}$ (urea group) and $T_{5}$ (protein supplemented group) could be linked to the additional protein supplied by the groups with the treatment materials. The crude fibre content of the sundried group $(26.80 \%)$ recorded highest value compared with the control diet. This could be attributed to the processing methods adopted in this study and the inherent high level of fibre in the cocoa pod husks. However, the values obtained for the experimental diets are higher than the minimum amount of crude fibre (12 $\%$ ) needed in a goat's diet (Hart 2008; Rashid 2008) and lower than the maximum amount of crude fibre (50\%) required in a goat's diet (Goatgyan, 2015). For a healthy rumen activity, the minimum level of crude fibre must be maintained as lower values will distort the rumen activity and nutrient utilization.

\section{Haematological characteristics of WAD bucks}

The haematological characteristics of WAD bucks fed diets containing CPHM (Table 4) differ significantly among dietary groups with the exception of neutrophils, eosinophils, basophils and MCV. The WBC counts recorded for the $T_{3}$ (UCPHM) and $T_{5}$ (protein supplemented) groups in this study did not differ from each other but were higher than the values of the WBCs of the $T_{1}$ (control), $T_{2}$ (SCPHM) and $\mathrm{T}_{4}$ (FCPHM) groups. The WBCs of the $T_{1}$ $\left(20.51 \times 10^{9} / \mathrm{L}\right), \mathrm{T}_{2}\left(12.14 \times 10^{9} / \mathrm{L}\right)$ and $\mathrm{T}_{4}\left(23.40 \times 10^{9} / \mathrm{L}\right)$ groups all fell within the recommended range (6.80 $\left.20.10 \times 10^{9} / \mathrm{I}\right)$ reported by Daramola et al. (2005) for WAD goats in Nigeria. The higher WBC values in the urea treated and protein supplemented groups could be attributed to immuno-response which may have resulted from handling of the urea and antinutrient components of the protein feedstuff (African yambean) used. The values of lymphocytes (16.40 - 30.11\%) and monocytes $(4.71-9.44 \%)$ in this study were significantly $(P<0.05)$ different between dietary treatments. This also indicated the presence of foreign bodies in the blood of the animals. The PCV values recorded in this study were lower than the range reported by Daramola et al. (2005) and Opara et al. (2010); while the haemoglobin contents recorded are within the range reported by the same workers. The PCV values of urea treated and protein supplemented groups were higher than the other treatment groups. This could be attributed to the increase in protein content of the test ingredients upon processing. The high haemoglobin values of the animals in this study could be linked to the observation made by Daramola et al. (2005) that WAD goats are known to have higher haemoglobin which gives them an edge over other breeds in the effective transport of oxygen in the blood. RBC shows the concentration of the red blood cell in the blood. The RBC values $(2.51-5.52$ $\left.\mathrm{x} 10^{12} / \mathrm{I}\right)$ in this study decreased with decreasing value of the PCV and vice versa. This observation is supported by the reports of Chineke et al. (2006) who stated that the higher the PCV, the higher the red blood cell. Blood platelets are known for their role in the clotting of blood and low values are seen in the longer time it takes for clotting to occur (Etim et al., 2014). The platelets (2.19$\left.3.61 \times 10^{11} / \mathrm{L}\right)$ were within the range $\left(300-600 \times 10^{3} / \mu \mathrm{L}\right.$ which is equal to $3.00-6.00 \times 10^{11} / \mathrm{L}$ ) reported by Fielder (2016) for goats. The $\mathrm{MCH}$ value for the sundried group (36.97) was higher than control (35.14 pg/cell), UCPHM (26.81 pg/cell), FCPHM (34.84 pg/cell) and 23.04 $\mathrm{pg} / \mathrm{cell})$ groups but not statistically different $(P>0.05)$ from the $\mathrm{MCH}$ values of the control and FCPHM groups. However, the values recorded across the groups in this study were within the range $(37.80 \pm 2.2$ and $35.94 \pm 0.02$ $\mathrm{pg} /$ cell) recorded by Opara et al. (2010) for WAD goats and Njidda et al. (2013) for Kano brown goat kids, respectively. Generally, the differences in all the parameters measured in all groups could be as a result of varied methods of the test ingredients.

\section{Serum biochemical indices of WAD bucks}

The serum biochemical indices of WAD bucks fed diets containing CPHM (Table 5) recorded significant differences $(P<0.05)$ in most of the parameters measured. The calcium and creatinine contents recorded higher values in the urea treated groups. However, the calcium content (1.14-2.24 mmol/l) was within the range $(1.15-2.4 \mathrm{mmol} / \mathrm{l})$ reported by Daramola et al. (2005). Urea contents of the sundried $(6.57 \mathrm{mmol} / \mathrm{l})$, fermented $(6.17 \mathrm{mmol} / \mathrm{l})$ and protein supplemented $(6.57 \mathrm{mmol} / \mathrm{l})$ groups were not significantly different. However, the low value of blood urea recorded in the urea treated group $(5.57 \mathrm{mmol} / \mathrm{l})$ could be caused by over-hydration (Amber, 2016). Abdul Wahid (2000) agreed with this fact when he noted a high urea concentration and output in urine of animals on ad lib water regime. Total protein in the UCPHM $(7.40 \mathrm{~g} / \mathrm{dl})$ and protein supplemented $(7.40 \mathrm{~g} / \mathrm{dl})$ groups were not statistically different $(P>0.05)$ from each other but were higher than the values in the control $(6.34 \mathrm{~g} / \mathrm{dl})$, SCPHM $(6.20 \mathrm{~g} / \mathrm{dl})$ and FCPHM $(6.60 \mathrm{~g} / \mathrm{dl})$ groups. These values can be compared with the value $(7.89 \mathrm{~g} / \mathrm{dl})$ reported by Kraidees (2005) for Najdi ram lamb fed urea treated straw and soya bean meal supplemented diets. However, Abdel Hameed et al. (2013) reported a slightly lower value of total serum protein for lambs fed urea treated groundnut hull supplemented with different protein sources (groundnut cake, cotton seed meal and fish by-products). These variations in protein contents could be traced to the varying protein contents of the diets as well as the different animals used. Globulin content of the protein supplemented $(4.80 \mathrm{~g} / \mathrm{dl})$ group was the same with that of the urea group $(4.80 \mathrm{~g} / \mathrm{dl})$ and higher than the globulin of the control $(3.65 \mathrm{~g} / \mathrm{dl})$, SCPHM $(3.45 \mathrm{~g} / \mathrm{dl})$ and FCPHM $(4.00 \mathrm{~g} / \mathrm{dl})$ groups. These higher levels in the globulin of the urea and protein supplemented groups could be linked to their dietary intake as reported by Tothova et al. (2016) who stated that albumin and globulin contents are dependent 
on the amount of total protein in the serum. The cholesterol content of the sundried group was the highest $(3.27 \mathrm{mmol} / \mathrm{l})$ and the lowest was in the protein supplemented group $(2.67 \mathrm{mmol} / \mathrm{l})$. The values recorded in the different groups could have resulted from dietary treatments. This was so because the protein supplement (African yambean) used in the study has a cholesterol reducing ability (Eneh et al., 2005). Total protein (TP), urea, sodium, cholesterol and triglycerides recorded in this study were within the ranges (TP, 6.30-8.50g/100ml; urea, 0.80-9.70 mmol/l; sodium, 124.00-146.00 mmol/l; triglycerides, $0.16-1.60 \mathrm{mmol} / \mathrm{l}$ and $\mathrm{TP}, 69.00 \pm 1.33 \mathrm{~g} / \mathrm{L}$; urea, $8.50 \pm 0.01 \mathrm{mmol} / \mathrm{l}$; sodium, $156.00 \pm 2.22 \mathrm{mmol} / \mathrm{l}$; cholesterol, $3.10 \pm 0.27 \mathrm{mmol} / \mathrm{l})$ reported by Daramola et al. (2005) for WAD goats and Njidda et al. (2013) for Sokoto red bucks respectively. This means that the diets supplied the needed amount of protein, urea, cholesterol and triglycerides for the maintenance of their different levels in serum composition.

\section{CONCLUSION}

In conclusion, the CPHM (processed and unprocessed) could be included up to $40 \%$ in the diet of WAD bucks with best results obtained when supplemented with African yam bean (10 \%) as protein supplement. The blood characteristics (haematology and serum chemistry) were best in the urea-treated and protein supplemented groups, respectively.

\section{REFERENCES}

Abdel Hameed, A. A. Salih, A. M., Fadel Elseed, A. M. and Amasaib, E. O., 2013. Effect of feeding untreated or urea treated groundnut hull supplemented with different protein sources on blood parameters of Sudan Desert lambs. Journal of Animal and Feed Research, 3(1): $40-46$.

Abdul wahid, A., 2000. The effect of water deprivation and atropine administration on gastro-intestinal function in goats. An M.Sc. Dissertation submitted to the Department of Veterinary Physiology, Faculty of Veterinary Science, University of Pretoria, Pretoria.

Abiola, S. S. and Tewe, O. O., 1991. Chemical Evaluation of Cocoa by-product. Tropical Agriculture (Tinidad), 68: 335-336.

Adamafio, N. A., Ayombil, F. and Tano-Debrah, K., 2011. Microbial detheobromination of cocoa (Theobroma cacao) pod husk. Asian Journal of Biochemistry, 6: 200 - 207.

Adegunloye, D. V. and Famolu, O. F., 2016. Influence of Fermentation on the nutritional content of cocoa pod (Theobroma cacao.L.). Journal of Global Biosciences, 5(1): 3408-3413.

Adugna, T., Roger, C. M., Arthur, L. G., Tilahun, S. and Tegene, N,. 2000. Nutritional constraints and future prospects for goat production in East Africa. In: The opportunities and challenges of enhancing goat production in East Africa.
Available

at:http://www.luresext.edu/?q=content/nutritional -constraints-and-future-prospects-goatproduction-east-africa. Accessed

on 23/03/2017.

Agunbiade, J., Adeleye, M. O. and Olubamiwa, O., 2002. Nutrient value of extruded cocoa husk meal in diets for broiler chicken. Proceedings of $27^{\text {th }}$ Annual Conference of Nigerian Society for Animal Production, March, 17-21. Pp. 132-134.

Akinmutimi, A. H., 2004. Evaluation of sword bean, Canavalia gladiata, as an alternative feed resource for broiler chickens. Ph.D. Thesis, Michael Okpara University of Agriculture Umudike, Nigeria.

Alber-Lois, L. and Segal- Kischinevzky, C., 2010. Beer and wine makers. Nature Education 3 (9): 17.

Alexander, J., Benford, D., Cockburn, A., Cravedi, J. P. and Dogliotti, E., 2008. Theobromine as undesirable substances in animal feed. Scientific Opinion of the Panel on Contaminants in the Food Chain. The European Food Safety Authority (EFSA) Journal, 725: 1 - 66.

Amber, E. G., 2016. Blood Urea Nitrogen Test. Available at: http://www.healthline.com/health/blood-ureanitrogen-test. Accessed on 08/03/2017.

AOAC 1990. Association of Official Analytical Chemists. Official Methods of Analysis, $15^{\text {th }}$ Edition, Washington D. C., USA.

Aregheore, E. M., 2002. Chemical Evaluation and Digestibility of Cocoa (Theobroma cacao) by-products fed to goats. Tropical Animal Health and Production, 34 (4): 339 - 348.

Baker, I. J. and Silverton, R. E., 1978. Haematology. Introduction to Medical Laboratory Technology, London, Butterworth and co. Ltd.

Bello, K. O., Eruvbetine, D., Fanimo, O. A. and Aina, B. J., 2012. Sensible heat balance of egg-type chickens fed fermented and unfermented groundnut husk diets. Nigerian Journal of Animal Production, 39(1): 74 - 85.

Chineke, C. A., Olugun, A. G. and Ikeobi, C. O. N., 2006. Haematological parameters of rabbit breeds and crosses in Humid Tropics. Pakistan Journal of Biological sciences, 9 (11): 21022106.

Coe, S. D. and Coe, M. D., 1996. The true history of chocolate. Published by Thames and Hudson Limited, London, United Kingdom, $3^{\text {rd }}$ edition.

Daramola, J. O., Adeloye, A. A., Fatoba, T. A. and Soladoye, A. O., 2005. Haematological and 
biochemical parameters of West African Dwarf goats. Livestock Research for Rural Development, 17(5): 7- 8 .

Duncan, D. B., 1955. Multiple Range and Multiple Ftests. Biometrics (11): 1-42.

Eneh, F. U., Orjionwe, R. N. and Adindu, C. S., 2015. Effect of African Yam Bean (Sphenostylis stenocarpa) on serum calcium, inorganic phosphate, uric acid, and alkaline phosphatase concentration of male albino rats. Journal of Agricultural Science, 8 (1): 200 - 212.

Erika, B. L. and Anuraga, J., 2015. Improving nutritional quality of cocoa pods through chemical and biological treatments for ruminant feeding; In vitro and In-vivo evaluation. AsianAustralasian Journal of Animal Science, 28 (3): 343-350.

Esong, R. N., Etchu, K. A., Bayemi, P. H. and Tan, P. V., 2015. Effect of dietary replacement of maize with sundried cocoa pods on the performance of growing rabbits. Tropical Animal Health and Production, 47(7): 14111416.

Etim, N. N., Williams, M. E., Akpabio, U. and Offiong, E. E. A., 2014. Haematological parameters and factors affecting their values. Journal of Agricultural Science, 2(1): 37-47.

Ewuola, E. O. and Egbunike, G. N., 2008. Haematological and serum biochemical response of growing rabbit bucks fed dietary Fumonisin B1. African Journal of Biotechnology, 7(23): $4304-4309$.

Fagbenro, O. A., 1995. Evaluation of heat processed cocoa-pod husk meal as energy feedstuff in production diets for the Clariid catfish (Clarias isheriensis,Sydenham).

Aquaculture Nutrition. 1:221-225. Available at: http://dx.doi.org/10.1111/j.1365-

2095.1995.tb00047.x. Accessed on $12 / 09 / 2017$

Fielder, S. E. 2016. Hematologic Reference Ranges. Merck Veterinary Manual, Centre for Veterinary Health Sciences (CVHS), Oklahoma State University.

Available at: http://www.merckvetmanual.com/a ppendixes/reference-guides/hematologicreference-ranges. Accessed on 27/03/2017.

Goatgyan 2015. Importance of fibre in goat digestion; Microbial digestion system of carbohydrates. Available at: http://www.goatgyan.com/goatfeeding/importance-of-fiber. Accessed on: $10 / 02 / 2017$

Goggle Earth, 2016. Geonames geographical database. Courtesy of Goggle earth. Travelling luck for Calabar, Cross river State Nigeria. Latitude, longitude, elevation and map/satellite image. Accessed on 30/03/2017.

Hart, S., 2008. Meat Goat Nutrition. Proceedings 23rd Annual of the Goat Field Day, Langston University, Langston. Pp. 58-83.

ICCO 1998. How does fermentation process work on the cocoa bean and how long does it take? FAQ. ICCO, Westgate house, Ealing, London. W5 1YY, United Kingdom. Available at: www.icco.org. Accessed 22/09/2017.

ICCO 2000. International Cocoa Organization. Animal feed from cocoa. Available at: http://www.icco.org/questions/animalfeed.htm. Accessed on 10/03/20167

lyayi, E. A., Olubamiwa, O., Ayuk, A., Orowvegodo, S. and Ogunaike, E. F., 2001. Utilization of urea treated and untreated cocoa pod husk based diets by growing pigs: An on-farm study. Journal of Tropiculture, 19(3): 101-104.

Jansen, C. and Van Den Burg, K., 2004. Goat keeping in the tropics. In: Robert, C. (Ed.). Digigrafi, Wageningen Publishing, The Nertherlands. Pp. 1- 96 .

Joachim W. H. and Felicitas P. P., 2000. Cocoa-pod Husk Meal. Handbook on Ingredients for Aquaculture Feeds, Pp. 100 - 104.

Khajarern, S. and Khajarern, J., 1985. The utilization of crop by-products as animal feed in Thailand. The Utilization of Fibrous Agricultural Residues as Animal Feeds. IDP, Canberra, Pp. 3-17.

Kieser, L., 2012. Feeding dairy goats. Available at: http://www.extension.umn.edu/food/small farms/livestock/sheep-goats/feeding- dairygoats/. Accessed on 24/04/2017.

Kohn, R. A. and Allen, M. S., 1995. Enrichment of proteolitic activity relative to Nitrogen in preparation from the rumen for in vitro studies. Animal Feed Science Technology, 52(1/2): 114

Kraidees, M. S., 2005. Influence of Urea Treatment and Soybean Meal (Urease) Addition on the Utilization of Wheat Straw by Sheep. AsianAustralasian Journal of Animal Science, 18(7): 957-965.

Merck Manual 2012. Haematological reference ranges. Merck Veterinary Manual. Available at: http://www.merckmanuals.com/. Accessed on 23/04/2017.

Njidda, A. A., Hassan, I. T. and Olatunji, E. A., 2013. Haematological and biochemical parameters of goats of semi arid environment fed on natural grazing range land of northern 
Nigeria. 1OSR Journal of Agriculture and Veterinary Science (1OSR-JAVS), 3(2): 1-8.

NMA, 2018. Nigerian Meteorological Agency, Weather Report, Margaret Ekpo International Airport, Calabar, Cross River State, Nigeria.

Norton, B. W., 1998. The nutritive value of tree legumes. In: Gutteridge, R. C. and Shelton, H. M. (Eds.). Published by The Tropical Grassland Society of Australia Incorporated, St Lucia Queensland 4067. Forage Tree Legumes in Tropical Agriculture, Pp. 177-191.

Nwanze, K. F., 2014. Science agenda for agriculture in Africa: 'Connecting science' to transform agriculture in Africa. Forum for Agricultural Research (FARA), Accra, Ghana.

Ochei, J. and kolhatkar, A., 2007. Medical laboratory theory and practice, $6^{\text {th }}$ Edition, Mc GrawHill Publishing Company Limited, New York, U.S.A. 1338 PP.

Okpiliya, F.I., Effiong E.B.1., Imoke E. and Eja, E., 2013. Mangrove forest ecosystem utilization and depletion: Implication for occupational changes in Calabar South, Nigeria. European Journal of Sustainable Development 2(1): $\quad 149-162$.

Opara, M. N., Udevi, N. and Okoli, I. C., 2010. Haematological parameters and blood chemistry of apparently healthy West African Dwarf (WAD) goats in Owerri, South Eastern Nigeria. Newyork Science Journal, 3(8): 68-72.

Opeke, L. K., 2005. Tropical Commodity Tree Crops. $2^{\text {nd }}$ edition. Spectrum books Ltd. Ibadan.

Oyadeyi, O. S. Olaniyan, O. O., Olusola, O. O. and Omojola, A. B., 2011. Performance and carcass characteristics of weaned rabbits fed varying levels of unfermented and wood ash digested/ fermented cocoa pod husk meal (CPHM).

Proceedings of the $36^{\text {th }}$ Conference of Nigeria Society for Animal Production (NSAP), 13-16 ${ }^{\text {th }}$ March,
2011, University of Abuja, Nigeria. Pp 758 761.

Ozung, P. O., Oko, O. O. K. and Agiang, E. A., 2016. Chemical composition of differently treated forms of cocoa pod husk meal (CPHM). Asian Journal of Agricultural Sciences, 8(2): 5-9.

Peter, T., Biamonte, G. T. and Doumas, B. T., 1982. Total protein in serum, urine and cerebrospinal fluids; Albumin in serum. Selected Method of Clinical Chemistry. American Association for Clinical Chemistry, Washington, D. C. P. 9.

Rashid, M., 2008. Goats and their nutrition. Manitoba goat association. Available at: $\mathrm{p}: / /$ www.anitobagoats.ca. Accessed on 03/03/16.

Suitkno, A. I., 1997. Cocoa pod for Feeding of Ruminant Livestock. Wartazoa, 6:38-43.

Tothova, C., Nagy, O. and Kovac, G., 2016. Serum proteins and their diagnostic utility in veterinary medicine: a review. Veterinarni Medicina, 61(9): 475- 496.

Turner, A. H., Pike, M. J. and Francis, M. A., 2008. Haematology; What does your blood test mean?. In: Singh, I. Available at: mams.rmit.edu.au/hgfc58lk9pwc1.pdf.

Accessed on 7/11/2017.

Ukachukwu, S. N. and Obioha, F. C., 2000. Effect of time duration of thermal treatment on the nutritive value of Mucuna cochinriesis. Global Journal of Applied Sciences, 6: 1115.

Vetstreet., 2011. Serum biochemistry profile. Available at: $\quad$ http://www.vetstreet.com/care/serumbiochemistry-profile. Accessed on 16/03/17.

Wong, H. K. and Wan Zahari, M., 1997. Nutritive value of palm kernel cake and cocoa pod husks for growing cattle. Journal of Tropical Agriculture and Food Science, 25(1): 125131. 